\title{
Assessment of Trace Metals Pollution in Auto-Mechanic Workshop in Some Selected Local Government Area of Benue State, Nigeria
}

\author{
Odoh R. (Corresponding Author), Agbaji E.B. \& Kagbu J.A. \\ Chemistry Department, Ahmadu Bello University Zaria, Nigeria \\ Tel: 234-803-971-0059Ｅ-mail: odohraf@yahoo.com
}

Received: March 25, 2011

Accepted: April 8, $2011 \quad$ Published: December 1, 2011

doi:10.5539/ijc.v3n4p78

URL: http://dx.doi.org/10.5539/ijc.v3n4p78

\begin{abstract}
The determination of $\mathrm{Cd}, \mathrm{Co}, \mathrm{Cu}, \mathrm{Mn}, \mathrm{Ni}, \mathrm{Pb}$ and $\mathrm{Zn}$ in soils within motor parks in some selected Local Government Areas of Benue state were carried out with Flame Atomic Absorption Spectrophotometric technique. The method developed by the United State Environmental Protection Agency for (total sobbed) heavy metals in soils, sediments and sludges was used in the preparation of the soil samples for the determination of total metal content in this study. Generally, the ranges and mean concentrations $(\mu \mathrm{g} / \mathrm{g})$ of metals in auto-mechanical workshop soils were $5.00-5.93(5.47 \pm 0.29), 2.07-2.93(2.44 \pm 0.28), 204.33-273.83(240.29 \pm 23.04)$, $402.00-486.67(436.91 \pm 35.53), 17.87-22.23(19.23 \pm 1.02), 513.00-582.00(567.52 \pm 19.35)$ and $106.67-$ 138.33 (119.02 \pm 8.77) for $\mathrm{Cd}, \mathrm{Co}, \mathrm{Cu}, \mathrm{Mn}, \mathrm{Ni}, \mathrm{Pb}$ and $\mathrm{Zn}$ respectively. The enrichment factors obtained for $\mathrm{Cd}$, $\mathrm{Co}, \mathrm{Cu}, \mathrm{Mn}, \mathrm{Ni}, \mathrm{Pb}$ and $\mathrm{Zn}$ in auto-mechanical workshops were 19.54, 1.80, 29.63, 3.03, 1.80, 172.50 and 12.45 respectively. The inter-element correlation was found among metals in the soils of auto-mechanical workshops using Pearson's correlation co-efficient. There were positive correlations among the metals determined. Metals such as $\mathrm{Pb}, \mathrm{Cd}, \mathrm{Cu}$ and $\mathrm{Zn}$ show high degree of contamination, while $\mathrm{Co}, \mathrm{Mn}$ and Ni shows low degree of contamination in the study sites.
\end{abstract}

Keywords: Heavy Metals, Auto-mechanic workshop, Benue State

\section{Introduction}

The use of metals in human history has yielded great benefit as well as unexpected harmful consequences. Heavy metal refers to chemical elements with a specific gravity that is at least 5 times the specific gravity of water. The specific gravity of water is 1 at $4{ }^{\circ} \mathrm{C}\left(39^{\circ} \mathrm{F}\right)$ (Maile, 2007). Although metals constitute the majority of elements by type, in general they represent a small atomic and mass fractional abundance of the element comprising the earth's surface and atmosphere relative to the non-metals (Allen et al., 1989). Further, while sharing common properties, metals exhibit wide ranges with respect to one another, in both chemical behavior and the measured values of those common properties. Historically, it has been the exploitation of these properties of metals which has led to successive waves of progress in the development of our modern technological society and its dependence on, and increasing appetite for metals (Alloway, 1995).

Man's perturbation of nature's slowly occurring life cycle of metals include (i) the extraction smelting and processing of metal bearing ores into products, (ii) the distribution and use of these products by industry and consumers and (iii) the return of these metals in a concentrated form to the natural environment through disposal of processing wastes and the discard or spent products. The metal or metals then become contaminants in the receiving environments. The pollution of environment by toxic metals is a serious environment issue especially by automobile sources (Akbar et al., 2006). This is due to the health implication of their presence, since they are non-essential metals that are not required for any function either by plants or animals. These metals are released during different operations of the auto-mechanic such as fluid leakage component wear, engine oils and corrosion of metals contribute immensely to soil contamination. Lead, cadmium, copper and zinc are the major metal pollutants of the auto-mechanical workshop and are released from fuel burning, of wear out tyres, leakage of oils and corrosion of batteries and metallic parts such as radiators (Dolan et al., 2006).

As population increased and technology improved and expanded, more significant and wide spread problems (environmental pollution) arose causing a continuing and accelerating decline in the quality of the environment and its ability to sustain life. However, level of these metals in the environment has increased tremendously in the past decades as a result of human inputs and activities. Some of the input of these metals result from 
activities related to industrialization, including combustion of fuels, or other temperature driven reactions associated with motor vehicle performance (Sawyer, 1998). $\mathrm{Cd}, \mathrm{Cu}, \mathrm{Pb}$, and $\mathrm{Zn}$ are fuel additives that are released into the atmosphere and carried to the soil through rain and wind (Mohammed et al., 2005). Benue state especially urban areas may not be an exception to the foregoing trace metal contamination problem. During the past decades, Benue metropolis especially Otukpo, Gboko and Makurdi has experienced a steady increase in the number of auto-mechanical workshops which operated virtually every corner of the streets apart from mechanic village set up by state government (Baiza, 1993; Baker \& Amachar, 1982).

The main purpose of this study therefore is to investigate heavy metals concentration at auto-mechanic workshop (which is located at Otukpo, Gboko and Makurdi) soil which would be useful in monitoring pollution status of these auto-mechanical workshops in the areas for environmental awareness. Since no such work has been reported in those areas, it is expected that the results would form a base line data for future heavy metal pollution status of the respected areas in the state (Aguniabde, 1989).

\section{Research Methods}

Sampling spots of about 20 - 30 m apart from each other were mapped out for soil sample collection within each sampling sites. Samples were collected using clean stainless steel trowel from about $0-15 \mathrm{~cm}$ depth. A soil sample for each control sites were also collected from where farming, mining and industrial activities were absent. The collected soil sub-samples were thoroughly mixed, pooled together to make a composite of each soil sample.

The collected soil samples were air-dried for some weeks to remove excess moisture. Large soil clods were also crushed to facilitate the drying. The dried soil samples were crushed in a porcelain mortar with a pestle. The crushed soil sample were sieved through a $2 \mathrm{~mm}$ sieve made of stainless steel, for analyzing soil $\mathrm{pH}$ and particle size, some portion of the individual sieved soil samples were further pulverized to a fine powder and passed through a $0.5 \mathrm{~mm}$ sieve for analyzing organic carbon and total metal content. The $\mathrm{pH}$ of the soil samples was determined with $\mathrm{pH}$ meter Hanna (Model H1991000) according to standard analytical methods. Organic matter was determined using the chromic acid oxidation method (Walkely \& Black, 1934). Particle size distribution was determined by the hydrometer method as described by Bauyocos (1951). The exchangeable cation was determined by the method described by Hendershot et al. (1993).

The method developed by the United States Environmental Protection Agency for (total sobbed) heavy metals in soil, sediments and sludged (USEPA SW-846, method 3050) (USEPA 1986), was used in the preparation of the soil samples for the determination of total metal content in this study. One gram $(1 \mathrm{~g})$ of the soil sample was weighed into a beaker for acid digestion. Analar grade nitric acid, hydrogen peroxide (about 30\%) and concentrated hydrochloric acid were used for the digestion. The digest was filtered through Whatman filter paper. Each filtrate was collected in $100 \mathrm{ml}$ volumetric flask and deionized water was used to rinse the filter paper into volumetric flask. Each filtrate was later made up to $100 \mathrm{ml}$ with deionized water. Standards were prepared with serial dilution techniques within the range of each metal determined. The standards used were Analar grade; the instrument was first calibrated with stock solutions of the prepared standards before analyzed using Flame Atomic Absorption Spectrophotometer (FAAS). After every five samples analyzed using FAAS, the first sample was repeated for quality check. Only when the result was within $10 \%$ of earlier readings did the analysis proceed further. The data obtained in the study were analyzed using Pearson correlation analysis.

The enrichment factors for the soils were calculated according to the following equation:

$\mathrm{EFc}=(\mathrm{Cx} / \mathrm{CFe})$ soil/ $/ \mathrm{Cx} / \mathrm{CFe})$ Earth's crust

Where $(\mathrm{Cx} / \mathrm{CFe})$ soil is the ratio of concentration of the element being determined $(\mathrm{Cx})$ to that of $\mathrm{Fe}(\mathrm{CFe})$ in the soil sample and $(\mathrm{Cx} / \mathrm{CFe})$ earth's crust is the ratio in the reference Earth's crust (Huheey, 1983).

\section{Results and Discussion}

\subsection{Soil Characteristics}

The $\mathrm{pH}$ values ranged from $6.40-7.20,6.80-7.20$ and $6.60-7.80$ for Otukpo, Gboko and Makurdi auto-mechanic workshop soil samples respectively (Tables 1-4). All the soils studied were either weakly acid or neutral.

The soil organic carbon concentrations ranged from $0.75-0.95,0.75-1.30$ and $0.76-1.30$ for Otukpo, Gboko and Makurdi respectively. The soils from the three study areas were generally low in organic carbon contents. Most of the soil samples studied from Otukpo, Gboko and Makurdi auto-mechanic workshop soil samples have organic carbon values of less than $2.00 \%$. The clay contents ranged from $13.40-17.60 \%, 8.20-9.40 \%$ and 8.00 
- $16.00 \%$ for Otukpo, Gboko and Makurdi auto-mechanic workshop soils respectively. The cation exchange capacity ranged from $12.20-16.50 \mathrm{meq} / 100 \mathrm{~g}, 12.20-17.20 \mathrm{meq} / 100 \mathrm{~g}$ and $14.50-20.15 \mathrm{meq} / 100 \mathrm{~g}$, for Otukpo, Gboko and Makurdi respectively.

\subsection{Heavy Metals Concentrations}

The results of heavy metal concentrations in the auto-mechanical workshops soil samples are presented in Tables 5-8. The soil samples from auto-mechanical workshops in the three major cities (Otukpo, Gboko and Makurdi) of Benue state revealed a clear elevated levels of these heavy metals ( $\mathrm{Cd}, \mathrm{Co}, \mathrm{Cu}, \mathrm{Mn}, \mathrm{Ni}, \mathrm{Pb}$ and $\mathrm{Zn}$ ). The mean concentrations of heavy metals obtained from the control sites were much lower than those obtained from the soils of the auto-mechanical workshop under consideration. This reflects a general and diffuse contamination of soils of these auto-mechanical workshops by heavy metals. Out of the heavy metals considered, lead shows the highest pollution in the three urban areas studied. The overall results ranged from $5.00-5.93 \mu \mathrm{g} / \mathrm{g}, 2.07-2.93$ $\mu \mathrm{g} / \mathrm{g}, 204.33-273.83 \mu \mathrm{g} / \mathrm{g}, 402.00-486.67 \mu \mathrm{g} / \mathrm{g}$, and $17.87-22.23 \mu \mathrm{g} / \mathrm{g}, 513.00-582.00 \mu \mathrm{g} / \mathrm{g}$ and106.67 $138.33 \mu \mathrm{g} / \mathrm{g}$ for $\mathrm{Cd}, \mathrm{Co}, \mathrm{Cu}, \mathrm{Mn}, \mathrm{Ni}, \mathrm{Pb}$ and $\mathrm{Zn}$ respectively.

Generally, in the three urban area studied, the concentrations of the heavy metals were extremely high especially $\mathrm{Pb}, \mathrm{Cd}, \mathrm{Cu}, \mathrm{Zn}$ and $\mathrm{Mn}$. This is an indication that these heavy metals are the primary contaminant in the auto-mechanical workshop soils which was also reflected in the low level of these heavy metals obtained from the control sites in comparison with those obtained from the study sites. Also, the degrees of heavy metals pollution in auto-mechanical workshop soils which were determined by its enrichment factors were also high. From the mean results and accumulation factors, there is a clear indication that $\mathrm{Pb}, \mathrm{Cu}, \mathrm{Cd}$ and $\mathrm{Zn}$ are the great contaminant in auto-mechanical workshop soils where exhaust from vehicles and gasoline combustion primarily cause air pollution with the heavy metals especially lead particles reaching soils through dry and wet depositions (Awofolu, 2004). Studies have shown that motor vehicles constitute principal source of this metal (Verqkvist, 1986; Viverette et al., 1986). Soil $\mathrm{Pb}$ concentrations greater than $1.0 \mathrm{mg} / \mathrm{kg}$ generally indicate a local source of pollution (Kabata-pendias \& Pendias, 2003). Concern for Pb concentrations in auto-mechanical workshop soils whose level are above $500 \mu \mathrm{g} / \mathrm{g}$ may therefore arise principally due to the fact that the studied auto-mechanical workshop could also be identified as play ground or near residential areas where children play about freely, and for children, ingestion of contaminated soil is the most significant pathway for $\mathrm{Pb}$ (Chaney, 1989; EPA, 1993). During the developmental years from 12 - 24 months, children are particularly prone to environmental soil $\mathrm{Pb}$ through hand-to-mouth behavior. Mielke (1999) and Viverette et al. (1996) have also stated that the total tolerable daily intake (TTDI) for $\mathrm{Pb}$ of $6 \mu \mathrm{g}$ per day may easily be exceeded most especially from $\mathrm{Pb}$ accumulated in soils of outdoor play environment.

Although the mean concentrations of Mn were found to be very high in the auto-mechanical workshop soils, this metal may not be regarded as a primary contaminant in the study area, this is reflected in its accumulation factors which primarily determine its extent of contamination. The enrichment factors of $\mathrm{Mn}$ in auto-mechanical workshop soils were 2.96, 3.03 and 3.06 for Otukpo, Gboko and Makurdi respectively. Also, the mean concentration of $\mathrm{Mn}$ obtained from all the sites $(436.91 \pm 34.53 \mu \mathrm{g} / \mathrm{g})$ falls within the acceptable limits proposed by some countries in the world. For instance, the Romanian guide for heavy metals in the soil proposed between $900-1500 \mathrm{mg} / \mathrm{kg}$ for Mn. Hence it could be said that Mn originates from parent material in the soil.

Copper is regarded as soil contaminant in the auto-mechanical workshop soils. Its mean concentrations and enrichment factors were found to be very high in auto-mechanical workshop soil samples. The high Cu levels in the study areas may be attributed to the improper disposal of waste lubricants. The degree of contamination of $\mathrm{Cu}$ found from the factors of enrichment also reflects that $\mathrm{Cu}$ is highly accumulated in auto-mechanical workshop soil. The values 31.16, 31.65 and 27.96 (Table 9) obtained in each of urban areas were high.

The mean concentration of $\mathrm{Zn}$ in auto-mechanical workshop soil samples was $119.02 \pm 8.77 \mu \mathrm{g} / \mathrm{g}$. This was also found to be very high in comparison with those obtained from control sites. This clearly shows that $\mathrm{Zn}$ which seems to be mainly associated with traffic auto-mobile source can also be derived from tyre consumption. Zn can also be considered as one of the heavy metals which are components of tyres and engines and can be released during abrasion and wears. However, $\mathrm{Zn}$ cannot also be regarded as one of the prominent contaminants like $\mathrm{Pb}$ in the auto-mechanical workshop soil because the mean metal content obtained for $\mathrm{Zn}$ in the auto-mechanical workshop soils falls below some of the proposed ranged for $\mathrm{Zn}$ values in uncontaminated soil. The accumulation factor of $\mathrm{Zn}$ was much lower than that of $\mathrm{Pb}$.

The concentrations of $\mathrm{Cd}$ in auto-mechanical workshop soil samples ranged from $5.00-5.93 \mu \mathrm{g} / \mathrm{g}$. This was also found to be very high. The high Cd levels obtained from the soil samples of auto-mechanical workshop sites may be due to the motor vehicle repair such as body work, painting, soldering, brake fluid, engine oils, corrosion of 
metal, batteries and metal parts such as radiators and indiscriminate dumping of waste products introduces Cd into the sites. Furthermore, the average $\mathrm{Cd}$ concentration of $5.57 \pm 0.37 \mu \mathrm{g} / \mathrm{g}$ obtained in auto-mechanical workshop soil samples are higher than E.U and ICRCL limits of $1-3$ and $0-1 \mathrm{mg} / \mathrm{kg}$ in the soil. These high concentration of $\mathrm{Pb}, \mathrm{Cu}, \mathrm{Cd}$ and $\mathrm{Zn}$ may be associated with sampling location: auto-mechanical workshops: since other researchers (Onianwa et al., 2001; Francis, 2005; Oluwole et al., 1994) have stated that the degree of heavy metal pollution in urban areas varied according to location.

The concentrations of $\mathrm{Ni}$ and Co were very low in the auto-mechanical workshop soil samples so also their enrichment factors which do not have much variation. From these observations, Ni and Co does not contribute much towards the contamination of areas under study. The correlations were established among the various metals under consideration (Table 10). There were positive correlations between pairs of $\mathrm{Cd} / \mathrm{Co}, \mathrm{Co} / \mathrm{Cu}, \mathrm{Cd} / \mathrm{Zn}$, $\mathrm{Mn} / \mathrm{Pb}, \mathrm{Cd} / \mathrm{Cu}, \mathrm{Ni} / \mathrm{Zn}$ and $\mathrm{Pb} / \mathrm{Zn}$ in auto-mechanical workshop soils confirming their probable common origin.

\subsection{Enrichment factors}

If an enrichment factor is greater than unity, this indicates that the metal is more abundant in the relative to that found in the earth's crust. However, enrichment factors less than 5 may not be considered significant although they are indicators of metal accumulation, because such small enrichments may arise from differences in the composition of local soil material and the reference earth's crust used in EFc calculations. If the EFc values are greater than 5 , in this case they are considered to be soil pollution for related metals. $\mathrm{Pb}, \mathrm{Cu}, \mathrm{Cd}$ and $\mathrm{Zn}$ have the highest $\mathrm{EFc}$ values i.e 172.50, 29.63, 19.54 and 12.45 for $\mathrm{Pb}, \mathrm{Cu}, \mathrm{Cd}$ and $\mathrm{Zn}$ respectively. These high $\mathrm{EFc}$ value indicate that the source of accumulation of $\mathrm{Pb}, \mathrm{Cu}, \mathrm{Cd}$ and $\mathrm{Zn}$ originates mainly from anthropogenic contributions. The $\mathrm{Pb}$ showed high $\mathrm{EFc}$ which may be a pollution indicator for soils polluted by $\mathrm{Pb}$ to some extent, mainly originated from traffic, since soil samples were collected from auto-mechanical workshops. The important contributors of $\mathrm{Pb}$ in soils are the parent geological materials from which soils are derived, smelters, coal combustion and the widespread use of leaded petrol. $\mathrm{Pb}$ mainly enters soils by means of atmospheric dry and wet depositions and the disposal of sewage sludge. As a consequence of $\mathrm{Pb}$ and materials containing $\mathrm{Pb}$, substantially elevated levels of this element may be found in some local soils (Harrison \& Laxen, 1981).

$\mathrm{Cu}$ has the next high $\mathrm{EFc}$ value after $\mathrm{Pb}$ in the studied soil samples of auto-mechanical workshops. The important sources of $\mathrm{Cu}$ in the soil samples may be from corrosive metal waste materials, scrap and batteries and other motor part repaired. $\mathrm{Cd}$ and $\mathrm{Zn}$ also have high $\mathrm{EFc}$ values. There is much concern about the levels of $\mathrm{Cd}$ present in the environment, since it is a cumulative poison for mammals. Its main ways of entering the environment as a waste product are especially from metal refining and electroplating, and also from the chemical and paint industries (Grimshaw et al., 1989). Zn is also surface contaminant of studied soil samples from auto-mechanical workshops. Its accumulation may occur from atmospheric deposition originating from smelting activities (in association with lead), galvanized iron and steel, alloys, batteries, brass, rubber manufacture, mining and old tyres (Nyle et al., 1999). Enrichment factors for Co, Mn and Ni varied from 1.80 - 3.03, which indicates that the soils were not polluted by these metals. However $\mathrm{Co}$, Ni and Mn have EFcs somewhat higher than unity i.e. 1.80, 3.03 and 1.80 respectively, but these may not be a pollution indicator for the soils.

\section{Conclusion}

The results obtained from the analysis of topsoils collected from auto-mechanical workshops in various location in Otukpo, Gboko and Makurdi areas of Benue state in Nigeria indicated that the concentration of $\mathrm{Cd}, \mathrm{Co}, \mathrm{Cu}$, $\mathrm{Mn}, \mathrm{Ni}, \mathrm{Pb}$ and $\mathrm{Zn}$ were higher than those of control soil metals contents. The degree of contamination of $\mathrm{Pb}$ was the highest. $\mathrm{Cd}, \mathrm{Cu}$ and $\mathrm{Zn}$ also showed high degree of contamination in auto-mechanical workshops soils. From this reason, it could be predicted that the contaminations of $\mathrm{Pb}, \mathrm{Cd}$ and $\mathrm{Zn}$ are probably from anthropogenic sources, while those of $\mathrm{Co}, \mathrm{Cu}, \mathrm{Ni}$ and $\mathrm{Mn}$ may be from parent material in the soil. The only observed contaminants were $\mathrm{Pb}, \mathrm{Cd}, \mathrm{Cu}$ and $\mathrm{Zn}$ and their concentrations and enrichment factors were high in all the soils studied. The results do not provide information about changes in the levels of inorganic soil contaminants over time, but they do provide baseline data for comparisons in the future. Hence, overall levels of $\mathrm{Pb}, \mathrm{Cd}, \mathrm{Cu}$ and $\mathrm{Zn}$ contaminations are those, which call for closer monitoring in sites under considerations.

\section{References}

Aguniabde, B. (1989). Rationalizing jurisdication for industrial pollution control and impact management in Nigeria. J. Environ. Mang, 28, 11-24.

Akbar, K. F., Hale, W. H. G., Headley, A. D., \& Athar, M. (2006). Heavy metals contamination of roadside soils of Northern England. Soil and water Res., 1(4), 158-163. 
Allen, S.E, Grimshaw, H.M., \& Parkinson, J.A. (1989). Chemical analysis of Ecological materials. (2 ${ }^{\text {nd }}$ ed). London Blackwell sci. Pub.

Alloway, B.J. (1995). Heavy metals in soils. (2 $2^{\text {nd }}$ ed). B lackie Academic and professional, London.

Awofolu, O.R. (2005). A survey of trace metals in vegetation,soil and lower animals along some selected major Roads in metropolitan city of Lagos. Environmental monitoring and Assessment, 105, 431-447. http://dx.doi.org/10.1007/s10661-005-4440-0

Awofolu, O.R. (2004). Impact of Auto-mobile exhaust on level of lead in a commercial food bus terminals. Journal of Applied Sciences and Environmental management, 1(8), 23-27.

Baize, D. (1993). Soil science Analysis. A guide to current Use. John Wiley and sons. New York.

Baker, D. E., \& Amacher, M. C. (1982). Nickel, copper, zinc and cadmium. In: A. L. page et al. (Ed.). Methods of soil analysis. Part 2.2 ${ }^{\text {nd }}$ Ed. Agron. Monogr. 9. ASA and SSSA, Madison, WI. Pp 232-336.

Chaney, R. L. (1989). Scientific analysis of proposed sludge rule. Biocycle, 30, 80-85.

Davenport J., \& Davenport, J.L. (eds). The ecology of transportation managing mobility for the environment. Springer Netherlands, 275-331.

Dolan, L. M.J., Van Bohemen, H.,Whelan, P., Akbar, K. F. O., Malley, V. O, Leiry, G., \& Keizer, P.J. (2006). Toulerds the sustainable development of modern road ecosystem: In European Commission (EC) (1986). European Commission, Office for official publication of the European Communities. Luxemberg, Councildirective 66/278/EEC on the protection of the environment, and in particular of soil, when sewage sludge is used in agriculture.

Francis, D.A. (2005). Trace heavy metals contamination of soils and vegetation in the vicinity of livestock in Nigeria. Elec. J. Environ Agric., 4(2), 863-870.

Grimshaw H.M., Allen S.E., \& Parkinson J.A. (1989). In Chemical Aanalysis of Ecological Materials (S.E Allen, Ed.), $2^{\text {nd }}$ ed. Blackwell Sci. pub., London. PP 81-239.

Harrison, R.M., \& Laxen, D.P.H. (1981). Lead pollution: Causes and Control, pp.55-69, Chaoman and Hall, New York.

Heinrichs, H., \& Meyer, R. (1977). Distribution and cycling of major and trace elements in two central European $\begin{array}{llllll}\text { forest Ecosystems. } & J & \text { Environ. } & \text { Qual., } & 6 & \text { (4), }\end{array}$ http://dx.doi.org/10.2134/jeq1977.00472425000600040014x

Huheey, J.E. (1983). Inorganic chemistry, $3^{\text {rd }}$ ed., Harper and Row Publishers, New York. pp 912-913.

ICRCL. (1987). Inter-developmental Committee for the redevelopment of contaminated land, guide on assessment and redevelopment of contaminated land. Paper 59/83 $2^{\text {nd }}$ ed. Development of the environment, London.

Kabata-Pendias, A., \& Pendias, H. (1984). Trace elements in soils and plants. Boca Raton. Fl: CRC- Press, Inc, 107-129.

Kabata-Pendias. A., \& Pendias, H. (1992). Trace elements in soils and plants. CRC Press, London.

Maile, P. (2007). Health Effect of Exposure to heavy metals. University of Michingan, July 7. P6.

Mielke, H.W. (1999). Lead in the inner cities. Am. Sci., 87, 62-73.

Mohammed, S., Nkobobi, M., Georges-IVO, E., EKOSSE, O.T., \& Julius, A. (2005). Soil Heavy metal concentration patterns at two seed zones along the Gaborone-Tlokweng Border post Highway. Southeast Botswana-Journal of Applied science and environmental management, 10(2), 135-143.

Nriagu, J. O. (1996). A history of global metal pollution. Science, 272, 223-224. http://dx.doi.org/10.1126/science.272.5259.223

Nyle, C., Brandy, R., \& Weil, R. (1999). The nature and properties of soil (12 $2^{\text {th }}$ edition). Pp. 723-756.

Oniawa, P.C., Jaiyeola, M.O., \& Ezekenze, R.N. (2001). Heavy metal contamination of Topsoil in the vicinities of auto-repair workshop, gas station and motor parks in Nigeria city. Toxicol. And environmental chemistry, 1-4(84), 33-39. http://dx.doi.org/10.1080/02772240309820

Sawyer, R. (1998). Attachment A: summary of workshop on metal based fuel additives University of California, Berkely. 
United Nations Env. Programme Environmental Data Report. (1993-94). Basil Blackwell, Oxford.

United States Environmental Protection Agency. (1986). Test Methods for evaluating solid wastes. USEPA SW. 846. U. S. Govt Print. Office, Washington, D. C.

Uren. N. (1992). Forms, reaction, and availability of $\mathrm{Ni}$ in soil. Adv. Agon., 48, 141-195. http://dx.doi.org/10.1016/S0065-2113(08)60937-2

Verqkvist, B. (1986). Leaching of metals from a spruce forest soil as influenced by experimental acidification. Water Air Soil Pollut., 31, 901-916. http://dx.doi.org/10.1007/BF00284236

Viverette, L., Mielke, H.W., Brisco, M., Dixin, A., J.Schaefer, J., \& Pierre, K. (1996). Environmental health in minority and other underserved populations: Benign Methods for identifying lead hazards at Day care centre of New Orleans. Environ. Geochem. Health., 18, 41-45. http://dx.doi.org/10.1007/BF01757218

WHO Working Group. (1989). Lead Environmental Aspect. Environmental Health Cortena, No.85, 1989. WHO. (1997). Lead, Environmental Health Criterial No3, World Health Organisation, Geneva.

Table 1. Soil Characteristics of Otupko Automechanical Workshop

\begin{tabular}{ccccccc}
\hline Sample sites & $\mathbf{p H}$ & $\mathbf{O . C}$ & Sand & Silt & Clay & C.E.C meq/100g \\
\hline A & 6.40 & 0.75 & 74.70 & 11.70 & 13.60 & 14.40 \\
B & 6.50 & 0.85 & 72.70 & 13.90 & 13.40 & 12.20 \\
C & 6.60 & 0.86 & 71.70 & 10.70 & 17.60 & 13.40 \\
D & 7.20 & 0.95 & 72.70 & 10.70 & 16.60 & 15.50 \\
E & 7.00 & 0.94 & 70.70 & 15.90 & 13.40 & 16.50 \\
Cont1 & 7.20 & 0.60 & 74.40 & 10.40 & 15.20 & 14.20 \\
Cont 2 & 6.10 & 0.95 & 71.40 & 10.40 & 18.20 & 13.40 \\
Cont 3 & 6.90 & 0.94 & 72.40 & 13.40 & 17.20 & 12.80 \\
\hline
\end{tabular}

Table 2. Soil Characteristics of Gboko Automechanical Workshops

\begin{tabular}{ccccccc}
\hline Sample sites & $\mathbf{p H}$ & O.C & Sand (\%) & Silt (\%) & Clay (\%) & C.E.C meq/100g \\
\hline A & 6.80 & 0.76 & 74.10 & 17.70 & 8.20 & 14.50 \\
B & 6.90 & 0.75 & 76.10 & 14.70 & 9.20 & 12.20 \\
C & 7.20 & 1.30 & 70.10 & 20.50 & 9.20 & 13.40 \\
D & 6.80 & 0.95 & 74.10 & 16.50 & 9.40 & 16.50 \\
E & 7.00 & 0.98 & 73.10 & 17.50 & 9.40 & 17.20 \\
cont1 & 6.90 & 0.98 & 69.40 & 12.40 & 18.20 & 14.50 \\
cont2 & 7.20 & 0.85 & 70.40 & 13.40 & 16.20 & 16.20 \\
cont3 & 7.40 & 0.60 & 70.70 & 14.90 & 14.40 & 15.60 \\
\hline
\end{tabular}


Table 3. Soil Characteristics of Markurdi Automechanical Workshop

\begin{tabular}{ccccccc}
\hline Sample sites & pH & O.C & Sand (\%) & Silt (\%) & Clay (\%) & C.E.C meq/100g \\
\hline A & 6.60 & 0.93 & 70.70 & 13.70 & 14.60 & 14.50 \\
B & 6.80 & 0.85 & 78.10 & 13.90 & 8.00 & 20.15 \\
C & 7.20 & 0.75 & 72.70 & 13.90 & 13.40 & 16.20 \\
D & 7.50 & 1.30 & 74.10 & 16.50 & 9.40 & 15.50 \\
E & 7.80 & 0.76 & 72.70 & 10.70 & 16.60 & 16.60 \\
cont1 & 7.20 & 0.85 & 70.70 & 13.70 & 15.60 & 17.20 \\
cont2 & 7.00 & 0.70 & 70.90 & 13.50 & 15.60 & 16.20 \\
cont3 & 6.90 & 0.94 & 73.70 & 9.60 & 16.70 & 15.60 \\
\hline
\end{tabular}

Table 4. The ranges and mean of soil properties of automechanical workshop in the study area

\begin{tabular}{cccccccc}
\hline \multirow{2}{*}{ Town } & & \multicolumn{7}{c}{ Parameters } \\
\cline { 3 - 8 } & & $\mathbf{p H}$ & $\mathbf{O . C}$ & sand & silt & clay & C.E.C \\
\hline OTUKPO & Range & $6.40-7.20$ & $0.75-0.95$ & $70.70-74.70$ & $10.70-15.90$ & $13.40-17.60$ & $12.20-16.50$ \\
$\mathrm{n}=5$ & Mean & 6.74 & 0.87 & 72.5 & 12.58 & 14.92 & 14.4 \\
& S.D & 0.34 & 0.08 & 148 & 2.27 & 2.02 & 1.69 \\
Gboko & Range & $6.80-7.20$ & $0.75-1.30$ & $70.10-76.10$ & $14.70-20.50$ & $8.20-9.40$ & $12.20-17.20$ \\
n=5 & Mean & 6.94 & 0.95 & 73.5 & 17.38 & 9.08 & 14.76 \\
& S.D & 0.17 & 0.22 & 2.19 & 2.11 & 0.5 & 2.09 \\
Makurdi & Range & $6.60-7.80$ & $0.76-1.30$ & $70.70-78.10$ & $10.70-16.50$ & $8.00-16.60$ & $14.50-20.15$ \\
n=5 & Mean & 7.18 & 0.92 & 73.66 & 13.74 & 12.4 & 16.59 \\
& S.D & 0.47 & 0.23 & 2.76 & 2.06 & 3.6 & 2.14 \\
All soil & Range & $6.40-7.80$ & $0.75-1.30$ & $70.00-78.10$ & $10.00-20.50$ & $8.00-17.60$ & $12.20-20.15$ \\
n=15 & Mean & 6.95 & 0.91 & 73.22 & 14.57 & 12.13 & 15.25 \\
& S.D & 0.38 & 0.17 & 2.11 & 2.9 & 3.32 & 2.08 \\
\hline
\end{tabular}

$\mathrm{n}=$ number of soil within the site

$\mathrm{S} . \mathrm{D}=$ standard deviation 
Table 5. Total Metal Contents ( $\mu \mathrm{g} / \mathrm{g})$ of Otukpo Automechanical Workshop

\begin{tabular}{cccccccc}
\hline Sample sites & $\mathbf{C d}$ & $\mathbf{C o}$ & $\mathbf{C u}$ & $\mathbf{M n}$ & $\mathbf{N i}$ & $\mathbf{P b}$ & $\mathbf{Z n}$ \\
\hline $\mathbf{A}$ & 5.40 & 2.40 & 222.00 & 486.33 & 19.73 & 577.00 & 108.00 \\
B & 5.70 & 2.07 & 208.80 & 414.33 & 19.93 & 578.00 & 116.33 \\
C & 5.80 & 2.80 & 250.00 & 410.00 & 18.00 & 573.00 & 121.67 \\
D & 5.00 & 2.20 & 256.67 & 409.33 & 18.73 & 579.00 & 111.00 \\
E & 5.93 & 2.93 & 273.00 & 419.33 & 17.87 & 582.00 & 106.67 \\
Cont 1 & 0.35 & 1.40 & 8.00 & 145.00 & 10.20 & 3.80 & 10.50 \\
cont 2 & 0.30 & 1.10 & 7.50 & 144.80 & 9.80 & 36.00 & 11.20 \\
cont 3 & 0.20 & 1.50 & 7.80 & 143.50 & 11.50 & 3.50 & 11.80 \\
\hline
\end{tabular}

Table 6. Total Metal Contents ( $\mu \mathrm{g} / \mathrm{g})$ of Gboko Automechanical Workshop

\begin{tabular}{cccccccc}
\hline Sample sites & $\mathbf{C d}$ & $\mathbf{C o}$ & $\mathbf{C u}$ & $\mathbf{M n}$ & $\mathbf{N i}$ & $\mathbf{P b}$ & $\mathbf{Z n}$ \\
\hline A & 5.20 & 2.20 & 252.83 & 413.00 & 19.30 & 565.00 & 110.33 \\
B & 5.27 & 2.27 & 268.83 & 402.00 & 19.43 & 513.00 & 120.00 \\
C & 5.13 & 2.13 & 273.83 & 486.67 & 20.13 & 577.00 & 113.67 \\
D & 5.20 & 2.20 & 204.33 & 413.33 & 19.50 & 545.00 & 127.33 \\
E & 5.67 & 2.67 & 229.67 & 480.00 & 18.45 & 582.00 & 126.67 \\
cont 1 & 0.30 & 1.40 & 9.20 & 142.50 & 11.50 & 3.50 & 9.50 \\
cont 2 & 0.37 & 1.30 & 7.20 & 140.80 & 10.10 & 3.00 & 8.50 \\
cont 3 & 0.25 & 1.45 & 6.90 & 144.20 & 9.90 & 3.50 & 10.50 \\
\hline
\end{tabular}

Table 7. Total Metal Contents ( $\mu \mathrm{g} / \mathrm{g}$ ) of Makurdi Automechanical Workshop

\begin{tabular}{cccccccc}
\hline Sample sites & $\mathbf{C d}$ & $\mathbf{C o}$ & $\mathbf{C u}$ & $\mathbf{M n}$ & $\mathbf{N i}$ & $\mathbf{P b}$ & $\mathbf{Z n}$ \\
\hline A & 5.53 & 2.53 & 213.17 & 422.00 & 22.23 & 580.00 & 138.33 \\
B & 5.93 & 2.93 & 255.17 & 419.00 & 19.53 & 565.00 & 120.00 \\
C & 5.47 & 2.47 & 229.67 & 485.00 & 19.13 & 545.00 & 115.33 \\
D & 5.33 & 2.33 & 232.83 & 413.33 & 19.30 & 582.00 & 121.00 \\
E & 5.53 & 2.53 & 233.50 & 480.00 & 18.87 & 569.85 & 129.00 \\
cont 1 & 0.35 & 1.40 & 7.90 & 146.20 & 11.00 & 3.50 & 9.70 \\
cont 2 & 0.33 & 1.30 & 8.50 & 145.50 & 12.00 & 3.20 & 8.60 \\
cont 3 & 0.20 & 1.40 & 8.60 & 144.10 & 10.60 & 3.00 & 10.50 \\
\hline
\end{tabular}


Table 8 . Summary of total metal contents $(\mu \mathrm{g} / \mathrm{kg}$ ) of automechanic workshop in the study area

\begin{tabular}{|c|c|c|c|}
\hline Town & metal & Range & mean/S.D \\
\hline \multirow[t]{2}{*}{ Otukpo } & $\mathrm{Cd}$ & $5.00-5.93$ & $5.57 \pm 0.37$ \\
\hline & Co & $2.07-2.93$ & $2.48 \pm 0.37$ \\
\hline \multirow[t]{5}{*}{$\mathrm{n}=5$} & $\mathrm{Cu}$ & $208.80-273.00$ & $242.09 \pm 26.18$ \\
\hline & $\mathrm{Mn}$ & $409.33-486.33$ & $427.86 \pm 32.93$ \\
\hline & $\mathrm{Ni}$ & $17.87-19.93$ & $18.85 \pm 0.95$ \\
\hline & $\mathrm{Pb}$ & $573.00-582.00$ & $577.80 \pm 3.27$ \\
\hline & $\mathrm{Zn}$ & $106.67-121.67$ & $112.73 \pm 6.22$ \\
\hline \multirow[t]{2}{*}{ Gboko } & $\mathrm{Cd}$ & $5.13-5.67$ & $5.29 \pm 0.22$ \\
\hline & Co & $2.13-2.67$ & $2.29 \pm 0.22$ \\
\hline \multirow[t]{5}{*}{$\mathrm{n}=5$} & $\mathrm{Cu}$ & $204.33-273.83$ & $245.90 \pm 28.92$ \\
\hline & $\mathrm{Mn}$ & $402.00-486.67$ & $439.00 \pm 40.80$ \\
\hline & $\mathrm{Ni}$ & $18.45-20.13$ & $19.36 \pm 0.60$ \\
\hline & $\mathrm{Pb}$ & $513.00-582.00$ & $556.40 \pm 28.14$ \\
\hline & $\mathrm{Zn}$ & $110.33-127.33$ & $119.60 \pm 7.60$ \\
\hline \multirow[t]{3}{*}{ Makurdi } & $\mathrm{Cd}$ & $5.33-5.6 \# 93$ & $5.56 \pm 0.22$ \\
\hline & $\mathrm{Co}$ & $2.33-2.93$ & $2.56 \pm 0.22$ \\
\hline & $\mathrm{Cu}$ & $213.17-255.17$ & $232.87 \pm 14.97$ \\
\hline \multirow[t]{4}{*}{$\mathrm{n}=5$} & $\mathrm{Mn}$ & $413.33-485.00$ & $443.87 \pm 35.45$ \\
\hline & $\mathrm{Ni}$ & $18.87-22.23$ & $19.81 \pm 1.37$ \\
\hline & $\mathrm{Pb}$ & $545.00-582.00$ & $568.37 \pm 14.84$ \\
\hline & $\mathrm{Zn}$ & $115.33-138.33$ & $124.73 \pm 9.05$ \\
\hline \multirow[t]{3}{*}{ all soil } & $\mathrm{Cd}$ & $5.00-5.93$ & $5.47 \pm 0.29$ \\
\hline & $\mathrm{Co}$ & $2.07-2.93$ & $2.44 \pm 0.28$ \\
\hline & $\mathrm{Cu}$ & $204.33-273.83$ & $240.29 \pm 23.04$ \\
\hline \multirow[t]{4}{*}{$\mathrm{n}=15$} & $\mathrm{Mn}$ & $402.00-486.67$ & $436.91 \pm 34.53$ \\
\hline & $\mathrm{Ni}$ & $17.87-22.23$ & $19.34 \pm 1.02$ \\
\hline & $\mathrm{Pb}$ & $513.00-582.00$ & $567.52 \pm 19.35$ \\
\hline & $\mathrm{Zn}$ & $106.67-138.33$ & $119.02 \pm 8.77$ \\
\hline
\end{tabular}

$\mathrm{n}=$ number of soil sample

S.D $=$ standard deviation 
Table 9. Factors of accumulation of heavy metals in auto-mechanical workshop in the study site

\begin{tabular}{|c|c|c|}
\hline Town & Metal & Rainy season \\
\hline \multirow[t]{2}{*}{ Otukpo } & $\mathrm{Cd}$ & 19.89 \\
\hline & $\mathrm{Co}$ & 1.86 \\
\hline \multirow[t]{5}{*}{$\mathrm{n}=5$} & $\mathrm{Cu}$ & 31.16 \\
\hline & $\mathrm{Mn}$ & 2.96 \\
\hline & $\mathrm{Ni}$ & 1.80 \\
\hline & $\mathrm{Pb}$ & 168.45 \\
\hline & $\mathrm{Zn}$ & 10.09 \\
\hline \multirow[t]{2}{*}{ Gboko } & $\mathrm{Cd}$ & 17.06 \\
\hline & $\mathrm{Co}$ & 1.66 \\
\hline \multirow[t]{5}{*}{$\mathrm{n}=5$} & $\mathrm{Cu}$ & 31.65 \\
\hline & $\mathrm{Mn}$ & 3.08 \\
\hline & $\mathrm{Ni}$ & 1.84 \\
\hline & $\mathrm{Pb}$ & 166.92 \\
\hline & $\mathrm{Zn}$ & 12.59 \\
\hline \multirow[t]{3}{*}{ Makurdi } & $\mathrm{Cd}$ & 19.17 \\
\hline & $\mathrm{Co}$ & 1.87 \\
\hline & $\mathrm{Cu}$ & 27.96 \\
\hline \multirow[t]{4}{*}{$\mathrm{n}=5$} & $\mathrm{Mn}$ & 3.06 \\
\hline & $\mathrm{Ni}$ & 1.77 \\
\hline & $\mathrm{Pb}$ & 175.97 \\
\hline & $\mathrm{Zn}$ & 12.99 \\
\hline \multirow[t]{2}{*}{ all soil } & $\mathrm{Cd}$ & 19.54 \\
\hline & $\mathrm{Co}$ & 1.80 \\
\hline \multirow[t]{5}{*}{$\mathrm{n}=15$} & $\mathrm{Cu}$ & 29.63 \\
\hline & $\mathrm{Mn}$ & 3.03 \\
\hline & $\mathrm{Ni}$ & 1.80 \\
\hline & $\mathrm{Pb}$ & 172.5 \\
\hline & $\mathrm{Zn}$ & 12.45 \\
\hline
\end{tabular}


Table 10. Elemental correlation coefficient in automechanical workshop

\begin{tabular}{|c|c|c|c|c|c|c|c|c|}
\hline Town & metal & $\mathrm{Cd}$ & Co & $\mathrm{Cu}$ & $\mathrm{Mn}$ & $\mathrm{Ni}$ & $\mathrm{Pb}$ & $\mathrm{Zn}$ \\
\hline \multirow[t]{7}{*}{ Otukpo } & $\mathrm{Cd}$ & & $0.640 *$ & 0.095 & -0.169 & -0.345 & -0.023 & 0.23 \\
\hline & Co & & & $0.706^{*}$ & -0.071 & $-0.837^{*}$ & - & -0.052 \\
\hline & $\mathrm{Cu}$ & & & & -0.406 & $-0.975^{*}$ & 0.347 & -0.256 \\
\hline & $\mathrm{Mn}$ & & & & & 0.498 & -0.05 & -0.489 \\
\hline & $\mathrm{Ni}$ & & & & & & -0.053 & -0.073 \\
\hline & $\mathrm{Pb}$ & & & & & & & $-0.810^{*}$ \\
\hline & $\mathrm{Zn}$ & & & & & & & \\
\hline \multirow[t]{7}{*}{ Gboko } & $\mathrm{Cd}$ & & 1 & -0.319 & 0.379 & $-0.919 *$ & 0.311 & $0.574 *$ \\
\hline & Co & & & -0.319 & 0.379 & $-0.919 *$ & 0.311 & $0.574 *$ \\
\hline & $\mathrm{Cu}$ & & & & 0.149 & 0.453 & -0.092 & $-0.747 *$ \\
\hline & $\mathrm{Mn}$ & & & & & -0.053 & $0.807^{*}$ & 0.028 \\
\hline & $\mathrm{Ni}$ & & & & & & -0.186 & $-0.510^{*}$ \\
\hline & $\mathrm{Pb}$ & & & & & & & -0.148 \\
\hline & $\mathrm{Zn}$ & & & & & & & \\
\hline \multirow[t]{7}{*}{ Makurdi } & $\mathrm{Cd}$ & & $1.00 *$ & $0.682 *$ & -0.199 & 0.0245 & -0.201 & -0.072 \\
\hline & Co & & & $0.682^{*}$ & -0.199 & 0.0245 & -0.201 & -0.072 \\
\hline & $\mathrm{Cu}$ & & & & -0.109 & $-0.636^{*}$ & -0.207 & $-0.628 *$ \\
\hline & $\mathrm{Mn}$ & & & & & -0.474 & $-0.710^{*}$ & -0.232 \\
\hline & $\mathrm{Ni}$ & & & & & & 0.45 & $0.775^{*}$ \\
\hline & $\mathrm{Pb}$ & & & & & & & $0.650 *$ \\
\hline & $\mathrm{Zn}$ & & & & & & & \\
\hline
\end{tabular}

*indicates the significance value

Correlation is significant at 0.05 level 